\title{
ISOLASI DAN KARAKTERISASI SENYAWA FLAVONOID DARI KULIT AKAR TUMBUHAN SUKUN Artocarpus altilis (Parkinson) Fosberg
}

\author{
Prio Santoso ${ }^{1}$, Tati Suhartati ${ }^{2}$
}

${ }^{1}$ Departemen Kimia, Fakultas Sains, Institut Teknologi Sumatera 35365

${ }^{2}$ Departemen Kimia, Fakultas Matematika dan Ilmu Pengetahuan Alam, Universitas Lampung 35145

\begin{abstract}
:
A flavonoid compound, artonin E (1), has successfully been isolated from root leather of Artocarpus altilis (Parkinson) Fosberg grown in the village of Banjar District State Tanggamus Wonosobo regency of Lampung Province. The structure of this compound has been carefully determined by ultaviolet-visible (UV-Vis) spectroscopy, infrared (IR) spectroscopy, nuclear magnetic resonance (NMR) spectroscopy, and based on physical data. The artonin E compound was obtained as amorphous yellow crystal with m.p. $247,5-249^{\circ} \mathrm{C}$.
\end{abstract}

Keyword: Artocarpus altilis, flavonoid, artonin E.

\section{Pendahuluan}

Indonesia dikenal sebagai salah satu dari 7 (tujuh) negara "megabiodiversity" kedua setelah Brazilia karena memiliki hutan tropika terbesar kedua di dunia yang kaya dengan keanekaragaman hayati. Distribusi tumbuhan tingkat tinggi yang terdapat di hutan tropika Indonesia lebih dari $12 \%$ (30.000) dari yang terdapat di muka bumi (250.000). Sebagai mana telah diketahui bersama, tumbuh- tumbuhan tersebut telah dimanfaatkan manusia dalam kehidupan, sejak awal peradaban seperti untuk sandang, pangan, papan, energi, dan sumber ekonomi.

Di samping itu, yang tidak kalah menarik adalah setiap spesies tumbuhan merupakan sumber bahan kimia hayati (chemical resources), sehingga biodiversitas dapat dipandang sebagai suatu industri atau pabrik bahan kimiawi yang berproduksi sepanjang tahun menghasilkan bahan kimia berguna (Chemical Prospectives) melalui proses rekayasa bioteknologi alami[ ${ }^{11}$.

Banyak senyawa organik yang berhasil diisolasi dari produk alam yang telah digunakan untuk mengobati berbagai penyakit misalnya antibiotik, penisilin dan tetrasiklin. Akan tetapi, kebutuhan terhadap obat untuk berbagai jenis penyakit terus bertambah. Oleh karena itu, pencarian senyawa baru dari produk alam terus dilakukan. Hal ini bertujuan untuk mengatasi berbagai penyakit yang disebabkan oleh berbagai mikroorganisme seperti bakteri dan virus ${ }^{[2]}$.

Artocarpus adalah salah satu genus penting dari Famili Moraceae. Tumbuhan kelompok ini tersebar luas di daerah tropika dan subtropika. Di Indonesia, telah dilaporkan sekurang-kurangnya memiliki sekitar 40 spesies dari genus artocarpus. Lebih dari 60 senyawa fenolik yang telah diteliti dan dikarakterisasi, termasuk 27 senyawa baru dari 13 spesies dari genus artocarpus yang ada di Indonesia yang meliputi: $A$. champeden, $A$. lanceifolius, $A$. teysmanii, $A$. scortechinii, $A$. rotunda, $A$. maingayi, $A$. kemando, A. bracteata, A. altilis, A. fretessi, A. gomezianus, $A$. reticulatus dan $A$. glaucus ${ }^{[3]}$.

Pemanfaatan tumbuhan Artocarpus sebagai obat tradisional secara konvensional telah banyak dilakukan oleh masyarakat dan mengingat tumbuhan Artocarpus banyak mengandung senyawa flavonoid yang berpotensi sebagai senyawa obat ${ }^{[4]}$ maka perlu dilakukan penelitian terhadap tumbuhan Artocarpus. 
Artocarpus altilis yang telah dikenal oleh masyarakat dengan nama sukun sudah pernah diteliti sebelumnya, dan diperoleh beberapa senyawa derivat flavonoid seperti morusin, artonin $E$ (1), sikloartobilosanton dan artonol B. Senyawa tersebut dilaporkan memiliki toksisitas yang tinggi terhadap udang Artemia salina ${ }^{[5]}$.

Jumlah kandungan senyawa metabolit sekunder dalam tumbuhan terdistribusi pada berbagai bagian tumbuhan, dan dalam masing-masing bagian itu mempunyai jenis dan kuantitas senyawa yang relatif tidak sama ${ }^{[6]}$. Diketahui bahwa kecenderungan pembentukan senyawa-senyawa kimiawi tumbuhan pada satu spesies secara kualitatif pada dasarnya sama, namun perbedaan kuantitas dapat dipengaruhi oleh keadaan geografis dari tumbuhan tersebut.

Desa Banjar Negara Kecamatan Wonosobo Kabupaten Tanggamus Provinsi Lampung merupakan daerah yang memiliki potensi tumbuhan sukun yang cukup besar dan terletak dekat dengan pesisir pantai. Sehingga diperkirakan nutrisi-nutrisi yang dibutuhkan oleh tumbuhan untuk memenuhi kebutuhan hidup dan juga untuk metabolisme senyawa metabolit sekundernya tercukupi. Oleh karena itu, dilakukan penelitian terhadap tumbuhan sukun yang tumbuh di daerah tersebut.

Pemilihan kulit akar tumbuhan sukun (A. altilis) sebagai sampel pada penelitian ini dikarenakan bagian tumbuhan ini diperkirakan memiliki senyawa hasil metabolisme sekunder yang bervariasi. Hal ini disebabkan karena bagian akar merupakan bagian yang digunakan oleh tumbuhan untuk berinteraksi dengan lingkungan dalam memenuhi kelangsungan hidupnya. Oleh karena itu, proses metabolisme akan terjadi terus-menerus sehingga mendorong tumbuhan untuk memproduksi senyawa metabolit sekunder agar dapat mempertahankan diri terhadap perubahan lingkungan yang terjadi.

\section{Metodologi Penelitian}

\subsection{Alat}

Alat-alat yang digunakan dalam penelitian ini meliputi alat-alat gelas, penguap putar vakum, satu set alat distilasi, satu set alat kromatografi cair vakum (KCV), satu set alat kromatografi kolom (KK), satu set alat kromatografi flash, pengukur titik leleh, lampu UV merk Spektroline model ENF-240 C/F, pipet kapiler, spektrofotometer FT-IR, spektrofotometer ultraviolet-tampak dan spektrofotometer ${ }^{1} \mathrm{H}-\mathrm{RMI}$.

\subsection{Bahan}

Bahan yang digunakan adalah kulit akar tumbuhan sukun ( $A$. altilis) yang telah dikeringkan dan dihaluskan, diperoleh dari Desa Banjar Negara Kecamatan Wonosobo Kabupaten Tanggamus Provinsi Lampung. Pelarut yang digunakan untuk ekstraksi dan kromatografi berkualitas teknis yang telah didestilasi sedangkan untuk analisis spektrofotometer berkualitas pro-analisis (p.a). Bahan kimia yang dipakai meliputi diklorometana (DCM), etil asetat (EtOAc), metanol $(\mathrm{MeOH}), n$-heksana $\left(n-\mathrm{C}_{6} \mathrm{H}_{6}\right)$, akuades $\left(\mathrm{H}_{2} \mathrm{O}\right)$, serium sulfat $\left(\mathrm{Ce}\left(\mathrm{SO}_{4}\right)_{2}\right) 1,5 \%$ dalam $\mathrm{H}_{2} \mathrm{SO}_{4} 2 \mathrm{~N}$, silika gel Merck $\mathrm{G} 60$ untuk impregnasi, silika gel Merck 60 (35-70 Mesh) dan pati untuk KCV, KK, dan kromaografi flash, untuk KLT digunakan plat KLT silika gel Merck Kiesegal $60 \mathrm{~F}_{254} 0,25 \mathrm{~mm}$. Pereaksi geser untuk analisis spektrofotometer ultraviolet-tampak adalah natrium hidroksida $(\mathrm{NaOH})$, aluminium klorida $\left(\mathrm{AlCl}_{3}\right)$, asam klorida $(\mathrm{HCl})$ pekat, dan natrium asetat $\left(\mathrm{CH}_{3} \mathrm{COONa}\right)$.

\subsection{Prosedur Penelitian}

Sebanyak $2,5 \mathrm{~kg}$ kulit akar tumbuhan $A$. altilis yang telah dihaluskan, dimaserasi menggunakan etil asetat selama 24 jam dengan sekali maserasi sebanyak $500 \mathrm{gram}$. Maserasi dilakukan sebanyak tiga kali. Ekstrak etil asetat yang diperoleh kemudian dipekatkan menggunakan penguap putar vakum pada suhu $45-50^{\circ} \mathrm{C}$ dengan laju putaran $120 \mathrm{rpm}$. Ekstrak etil asetat kemudian difraksinasi dengan menggunakan kromatografi kolom dan dikontrol dengan kromatografi lapis tipis (KLT). Fraksi yang telah murni berdasarkan KLT selanjutnya dianalisis dengan spektrometer infra merah (IR), UV-Vis, dan spentrometer Nucleic Magnetic Resonance (NMR) untuk menentukan struktur molekulnya. 


\section{Hasil dan Pembahasan}

Dari penelitian ini telah berhasil diisolasi senyawa flavonoid murni dari kulit akar tumbuhan sukun yang diperoleh dari Desa Banjar Negara Kecamatan Wonosobo Kabupaten Tanggamus Provinsi Lampung. Senyawa flavonoid yang diperoleh berupa kristal berwarna kuning sebanyak $33 \mathrm{mg}$ dengan titik leleh sebesar 247,5-249 ${ }^{\circ} \mathrm{C}$. Selanjutnya senyawa tersebut ditentukan struktur molekulnya dengan spektrometer infra merah (IR), UV-Vis, dan spentrometer Nuclear Magnetic Resonance (NMR).

Penentuan struktur molekul senyawa yang diperoleh diawali dengan analisis menggunakan spektrofotometri ultraviolet-tampak. Analisis spektrofotometri ultraviolet-tampak ini pada dasarnya dilakukan dengan memperhatikan adanya sistem karbonil yang berkonjugasi dengan cincin aromatik pada suatu flavonoid. Hal ini yang menyebabkan senyawa flavonoid dapat menyerap cahaya pada panjang gelombang tertentu di daerah ultraviolet (UV). Senyawa flavon mempunyai serapan di daerah UV pada dua panjang gelombang, yaitu sekitar $310-350 \mathrm{~nm}$ pada pita I dan sekitar $250-280 \mathrm{~nm}$ pada pita $\|^{[7]}$.

Gambar 1 memperlihatkan data serapan senyawa hasil isolasi yang diperoleh dari kulit akar tumbuhan sukun (Artocarpus altilis) terhadap sinar UV yang memberikan serapan maksimum pada $\lambda_{\text {maks }} 268 \mathrm{~nm}$ dan $352 \mathrm{~nm}$ dalam metanol dengan konsentrasi $3 \mathrm{mg} / 100 \mathrm{~mL}$. Data spektrum UV menunjukkan karakteristik untuk senyawa flavon. Serapan maksimum di daerah ultraviolet pada $\lambda_{\text {maks }}$

$352 \mathrm{~nm}$ merupakan spektrum khas flavon pada pada pita I yang karakteristik untuk resonansi gugus sinamoil dari cincin B. Serapan maksimum pada $\lambda_{\text {maks }} 268 \mathrm{~nm}$ merupakan spektrum khas flavon pada pita II yang karakteristik untuk resonansi gugus benzoil dari cincin $A$.

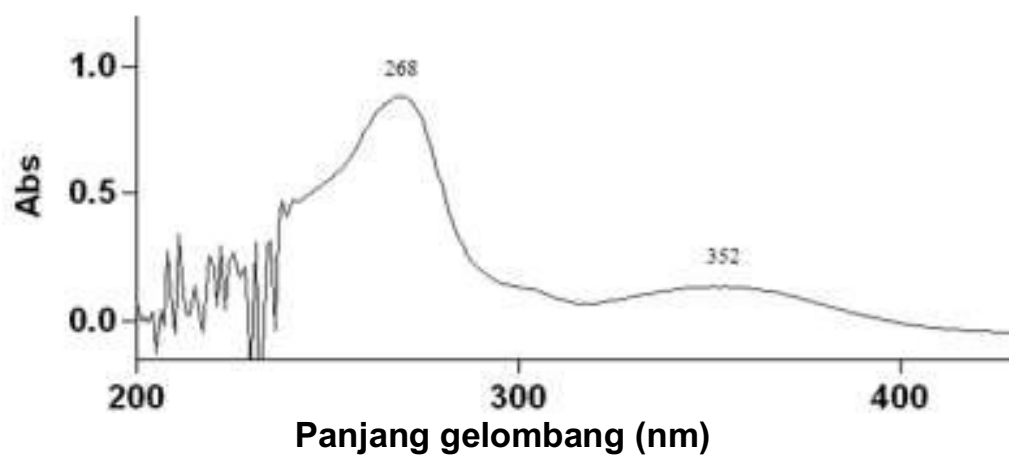

Gambar 1 Spektrum UV senyawa hasil isolasi dalam $\mathrm{MeOH}$.

Analisis berikutnya, yaitu dengan menggunakan spektrometri infra merah untuk melihat gugus fungsi yang terdapat pada senyawa yang diperoleh. Dari data spektrum IR senyawa hasil isolasi dapat diketahui adanya pita melebar pada daerah bilangan gelombang $3300-3600 \mathrm{~cm}^{-1}$, yaitu pada puncak $3433 \mathrm{~cm}^{-1}$ yang merupakan vibrasi ulur dari gugus hidroksil yang dapat membentuk ikatan hidrogen. Puncak serapan pada daerah $2982 \mathrm{~cm}^{-1}$ dan $2913 \mathrm{~cm}^{-1}$ merupakan petunjuk adanya gugus C-H alifatik. Puncak serapan pada daerah bilangan gelombang $1654 \mathrm{~cm}^{-1}$ menunjukkan adanya gugus karbonil $(C=O)$ yang berkonjugasi dengan $C=C$. Puncak-puncak serapan pada daerah $1561,1523,1482,1461$, dan $1429 \mathrm{~cm}^{-1}$ menunjukkan adanya $\mathrm{C}=\mathrm{C}$ aromatik. Spektrum IR senyawa hasil isolasi dapat dilihat pada Gambar 2. 


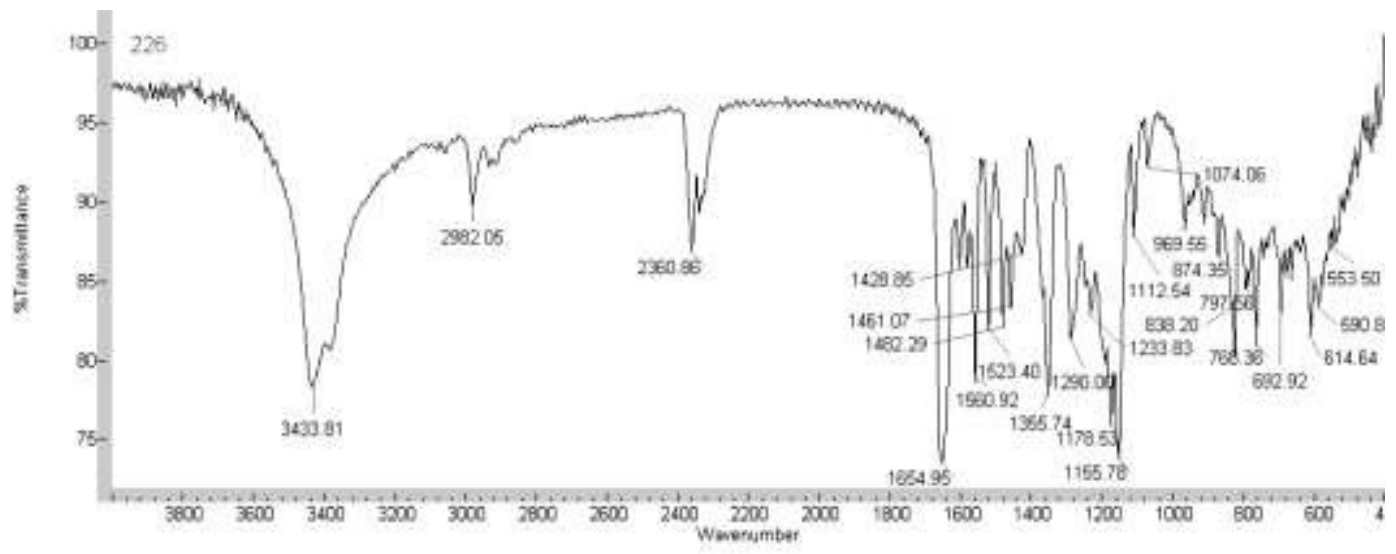

Gambar 2 Spektrum IR senyawa hasil isolasi.

Spektrum IR senyawa flavonoid hasil isolasi dari kulit akar sukun (Artocarpus altilis) menunjukkan adanya kemiripan dengan spektrum senyawa artonin $\mathrm{E}$ standar. Hal ini dapat dilihat dari perbandingan spektrum IR senyawa flavonoid hasil isolasi (Gambar 2) dengan senyawa artonin E standar (Gambar $3)$.

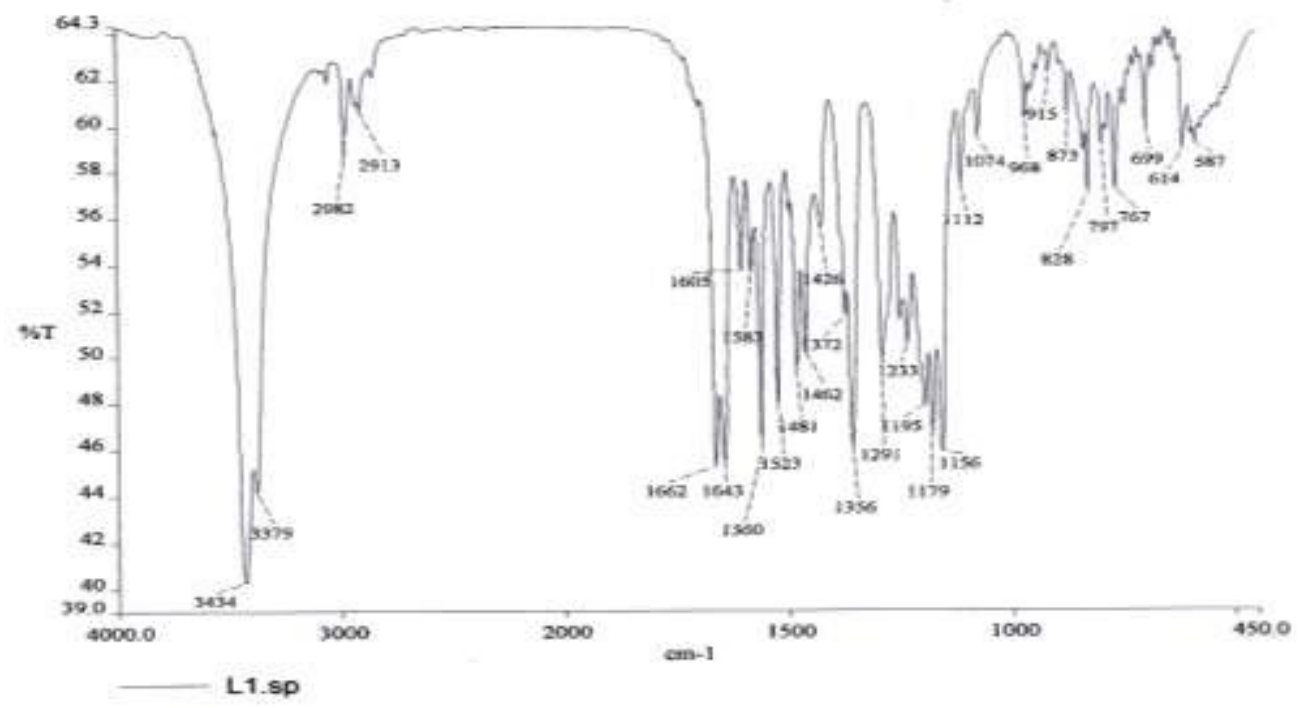

Gambar 3 Spektrum IR senyawa artonin E standar ${ }^{[8]}$.

Agar dapat dibuktikan bahwa kedua senyawa ini adalah identik, maka dilakukan perbandingan data senyawa hasil isolasi dengan senyawa artonin E standar yang dapat dilihat pada Tabel 1.

\begin{tabular}{|c|c|c|c|}
\hline \multicolumn{2}{|c|}{ IR $(\mathrm{KBr})$ vmaks $\left(\mathrm{cm}^{-1}\right)$} & \multicolumn{2}{c|}{$\mathrm{IR}(\mathrm{KBr})$ vmaks $\left(\mathrm{cm}^{-1}\right)$} \\
\hline A & B & A & B \\
\hline 3433 & 3434 & 1234 & 1233 \\
\hline 2982 & 2982 & 1113 & 1112 \\
\hline 2913 & 2913 & 1074 & 1074 \\
\hline 1655 & 1662 & 970 & 968 \\
\hline 1605 & 1605 & 915 & 915 \\
\hline 1561 & 1560 & 874 & 873 \\
\hline 1523 & 1523 & 798 & 797 \\
\hline 1482 & 1481 & 768 & 767 \\
\hline 1461 & 1462 & 693 & 699 \\
\hline
\end{tabular}

Tabel 1 Perbandingan data IR senyawa hasil isolasi (A) dengan senyawa artonin E standar (B). 
Setelah analisis spektrometer IR selanjutnya dilakukan analisis struktur dengan menggunakan spektrometri ${ }^{1} \mathrm{H}-\mathrm{NMR}$ dan ${ }^{13} \mathrm{C}$-NMR untuk mengetahui jumlah atom hidrogen dan karbon senyawa hasil isolasi serta kondisi lingkungannya. Hasil analisis ${ }^{1} \mathrm{H}-\mathrm{NMR}$ dengan pelarut aseton terdeteurasi (asetond6) pada frekuensi radio $500 \mathrm{MHz}$, standar internal trimetil silana (TMS) menunjukkan adanya 3 proton singlet aromatik pada geseran kimia 6,15 ppm pada cincin A, 6,59 ppm dan 6,87 ppm pada cincin B. Subtituen isoprenil pada $\mathrm{C}-3$ ditunjukkan oleh proton dari 2 gugus $\mathrm{CH}_{3}$ dengan geseran kimia 1,46 ppm $(3 \mathrm{H}, \mathrm{s})$ dan $1,57 \mathrm{ppm}(3 \mathrm{H}, \mathrm{s})$ dan 3 proton sistem $\mathrm{ABX}$ dengan geseran kimia $3,14 \mathrm{ppm}(2 \mathrm{H}, \mathrm{d})$ dan 5,12 ppm $(1 \mathrm{H}, \mathrm{t})$. Selain itu, cincin 2,2-dimetilkromen subtituen isoprenil pada $\mathrm{C}-8$ ditunjukkan oleh proton dari 2 gugus $\mathrm{CH}_{3}$ dengan geseran kimia $1,44 \mathrm{ppm}(6 \mathrm{H}, \mathrm{s})$ dan 2 proton dari gugus vinil yang terikat langsung pada cincin A dengan geseran kimia 6,62 ppm (1H, d) dan 5,65 ppm $(1 \mathrm{H}, \mathrm{d})$. Spektrum ${ }^{1} \mathrm{H}-$ NMR senyawa hasil isolasi dapat dilihat pada Gambar 4.

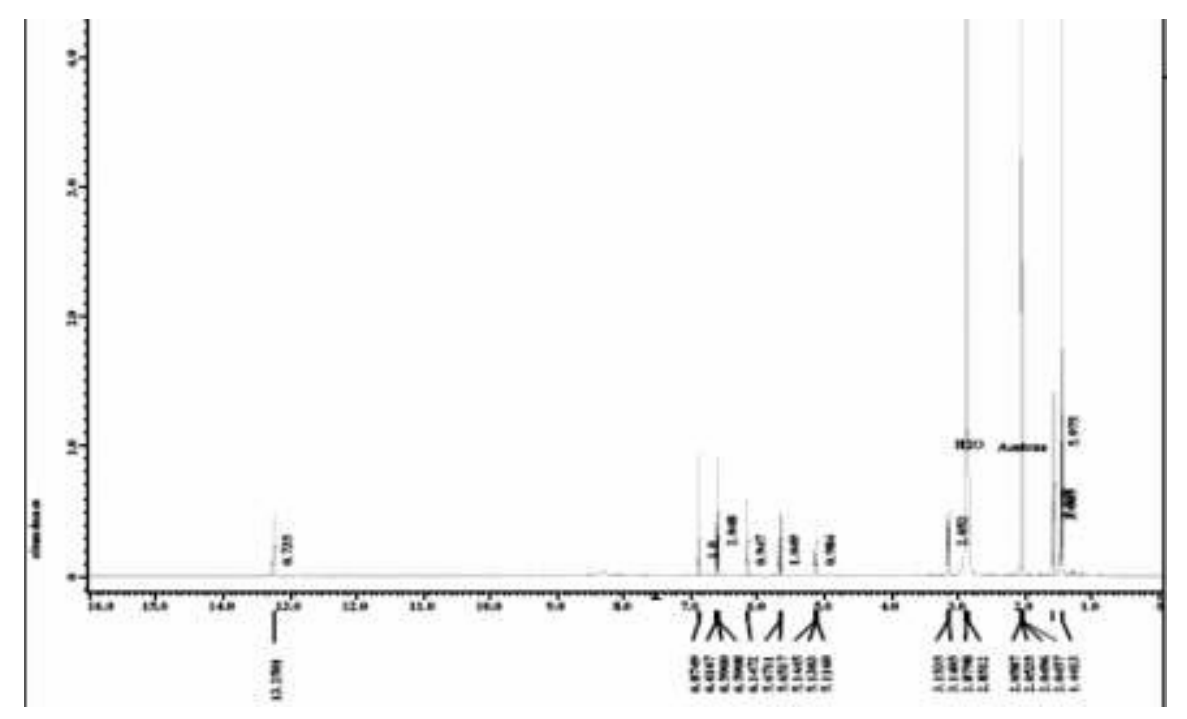

Gambar 4 Spektrum ${ }^{1} \mathrm{H}-\mathrm{NMR}$ senyawa hasil isolasi.

Berikut ini perbandingan hasil analisis ${ }^{1} \mathrm{H}-\mathrm{NMR}$ senyawa yang diperoleh dengan senyawa artonin $\mathrm{E}^{[8]}$.

\begin{tabular}{|c|c|}
\hline \multicolumn{2}{|c|}{${ }^{1} \mathrm{H}-\mathrm{NMR}, \delta(\mathrm{ppm})$} \\
\hline Artonin E (aseton-d6) & Senyawa hasil isolasi (aseton-d6) \\
\hline $1,44(6 \mathrm{H}, \mathrm{s})$ & $1,44(6 \mathrm{H}, \mathrm{s})$ \\
$1,46(3 \mathrm{H}, \mathrm{s})$ & $1,46(3 \mathrm{H}, \mathrm{s})$ \\
$1,57(3 \mathrm{H}, \mathrm{s})$ & $1,57(3 \mathrm{H}, \mathrm{s})$ \\
& \\
$3,14(2 \mathrm{H}, \mathrm{d}, \mathrm{J}=7 \mathrm{~Hz})$ & $3,14(2 \mathrm{H}, \mathrm{d}, \mathrm{J}=7 \mathrm{~Hz})$ \\
$5,13(1 \mathrm{H}, \mathrm{m})$ & $5,12(1 \mathrm{H}, \mathrm{t})$ \\
$5,66(1 \mathrm{H}, \mathrm{d}, \mathrm{J}=10 \mathrm{~Hz})$ & $5,65(1 \mathrm{H}, \mathrm{d}, \mathrm{J}=10 \mathrm{~Hz})$ \\
$6,15(1 \mathrm{H}, \mathrm{s})$ & $6,15(1 \mathrm{H}, \mathrm{s})$ \\
$6,59(1 \mathrm{H}, \mathrm{s})$ & $6,59(1 \mathrm{H}, \mathrm{s})$ \\
$6,60(1 \mathrm{H}, \mathrm{d}, \mathrm{J}=10 \mathrm{~Hz})$ & $6,62(1 \mathrm{H}, \mathrm{d}, \mathrm{J}=10 \mathrm{~Hz})$ \\
& \\
$6,88(1 \mathrm{H}, \mathrm{s})$ & $6,87(1 \mathrm{H}, \mathrm{s})$ \\
$7,80(1 \mathrm{H}, \mathrm{br} \mathrm{s})$ & \\
$8,28(1 \mathrm{H}, \mathrm{s})$ & \\
$8,34(1 \mathrm{H}, \mathrm{br} \mathrm{s})$ & $13,25(1 \mathrm{H}, \mathrm{s})$ \\
$13,25(1 \mathrm{H}, \mathrm{s})$ & \\
\hline
\end{tabular}

Tabel 2 Perbandingan hasil analisis ${ }^{1} \mathrm{H}-\mathrm{NMR}$ senyawa hasil isolasi dengan senyawa artonin $\mathrm{E}^{[8]}$.

Berdasarkan hasil analisis spektroskopi ultraviolet tampak, IR, dan ${ }^{1} \mathrm{H}-\mathrm{NMR}$ dapat disimpulkan bahwa senyawa hasil isolasi merupakan senyawa flavonoid turunan furano dihidrobenzosanton yang berasal 
dari suatu flavon yaitu artonin $\mathrm{E}(1)$. Kesimpulan ini didukung juga oleh data analisis spektroskopi ${ }^{13} \mathrm{C}$ NMR yang menunjukkan adanya 25 sinyal atom karbon. Pada $\delta$ (ppm): 153,32 (C-8a); 162,82 (C-7); 162,22 (C-2); 160,12 (C-8a); 149,80 (C-2'); 149,51 (C-4'); dan 139,14 (C-5') menunjukkan atom C aromatik yang mengikat gugus fungsi oksigen. Daerah $\delta(\mathrm{ppm})$ : 99,77 (C-6); 104,73 (C-3'); dan 117,11 (C-6') menunjukkan atom $\mathrm{C}$ aromatik yang mengikat atom $\mathrm{H}$. Atom $\mathrm{C}$ aromatik lainnya ditunjukkan pada $\delta$ (ppm): 105,65 (C-4a);121,72 (C-3); dan 111,60 (C-1'). Sedangkan pada $\delta=183,34$ ppm menunjukkan adanya atom $\mathrm{C}$ karbonil terkonjugasi. Posisi relatif kedua subtituen isoprenil pada kerangka isoflavon selanjutnya dibuktikan dengan bantuan HMBC (Gambar 9); proton metilen pada $\delta 3,14 \mathrm{ppm}(\mathrm{H}-9)$ menunjukkan korelasi jarak jauh dengan karbon karbonil pada $\delta 183,34$ ppm (C-4) dan $\delta 162,22$ ppm $(\mathrm{C}-2)$, sedangkan proton vinil pada $\delta 6,62 \mathrm{ppm}(\mathrm{H}-14)$ berkorelasi jarak jauh dengan karbon pada $\delta$ 160,12 ppm (C-8a), yang berarti bahwa gugus $\gamma-\gamma$

dimetilalil terikat pada posisi C-3 dan gugus 2,2-dimetilkromen terikat secara anguler pada C-7 dan C8. Hal ini sesuai yang dinyatakan oleh Suhartati $(2001)^{[9]}$.

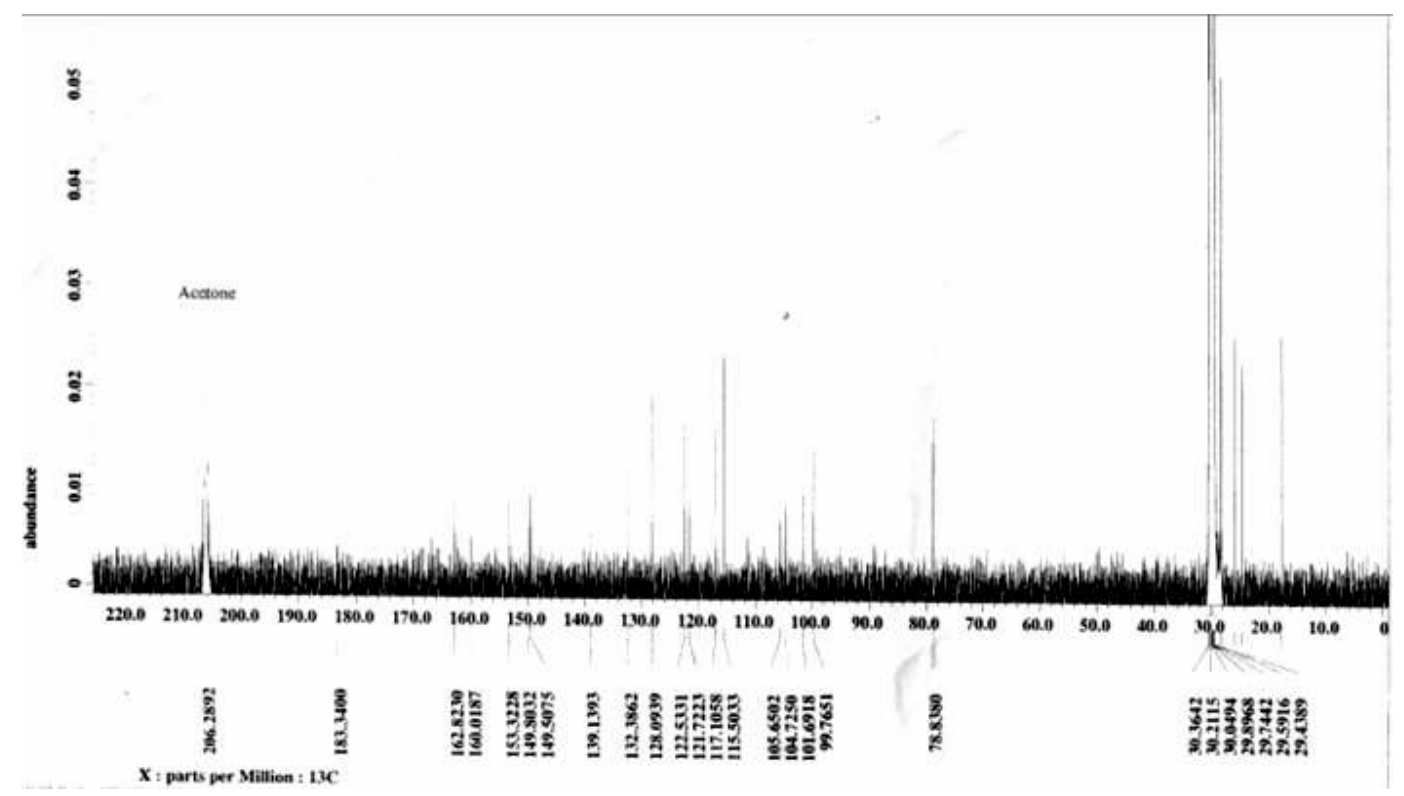

Gambar 5 Spektrum ${ }^{13} \mathrm{C}-\mathrm{NMR}$ senyawa hasil isolasi.

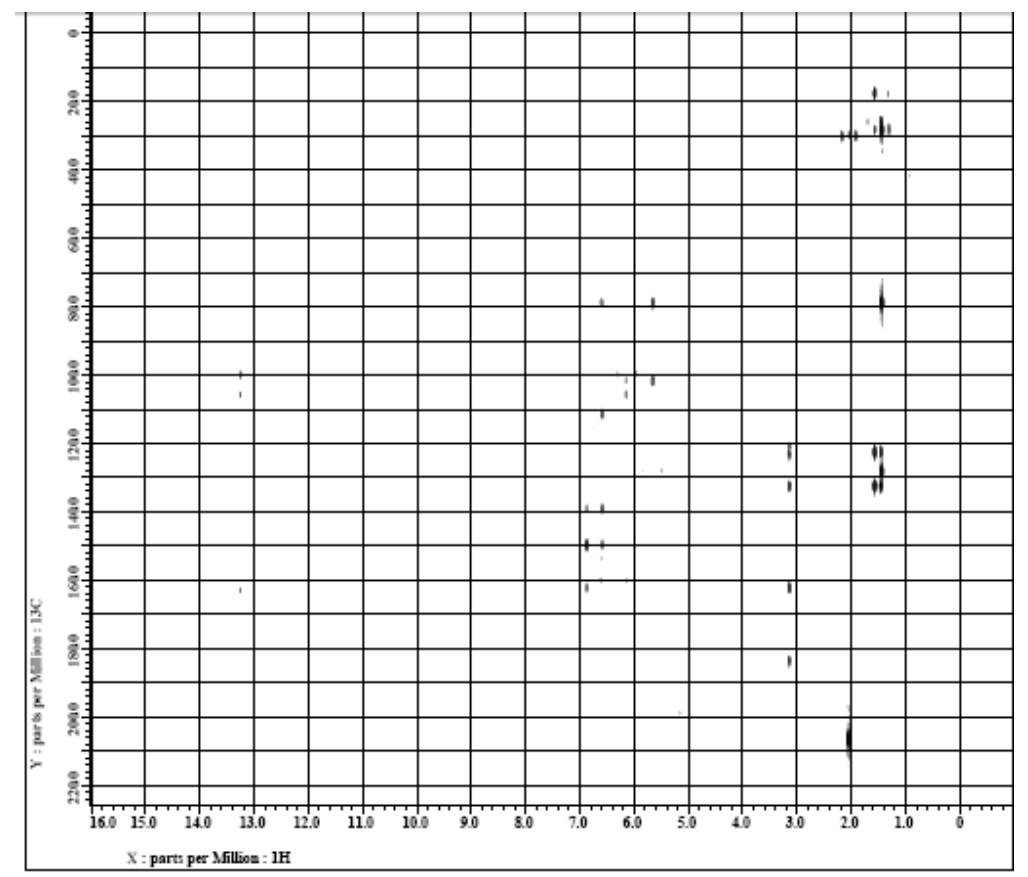

Gambar 6 Spektrum HMBC senyawa hasil isolasi. 


\begin{tabular}{|c|c|c|}
\hline \multicolumn{3}{|c|}{${ }^{13} \mathrm{C}-\mathrm{NMR}, \delta(\mathrm{ppm})$} \\
\hline No. C & Artonin $\mathrm{E}\left(\mathrm{CD}_{3} \mathrm{OD}\right)$ & Senyawa hasi isolasi (aseton-d6) \\
\hline 2 & 162,7 & 162,22 \\
3 & 122,0 & 121,72 \\
4 & 183,9 & 183,34 \\
$4 a$ & 105,9 & 105,65 \\
5 & 153,8 & 153,32 \\
6 & 100,1 & 99,77 \\
7 & 163,3 & 162,82 \\
8 & 102,2 & 101,69 \\
$8 \mathrm{a}$ & 160,5 & 160,12 \\
$1^{\prime}$ & 111,8 & 111,60 \\
2 & 150,1 & 149,80 \\
$3^{\prime}$ & 104,7 & 104,73 \\
$4^{\prime}$ & 150,0 & 109,51 \\
$5^{\prime}$ & 139,5 & 139,14 \\
6 & 117,2 & 117,11 \\
9 & 24,9 & 24,74 \\
10 & 122,6 & 122,53 \\
11 & 133,0 & 132,89 \\
12 & 25,87 & 25,90 \\
13 & 17,63 & 17,71 \\
14 & 115,8 & 115,50 \\
15 & 128,2 & 128,09 \\
16 & 79,1 & 78,84 \\
17 & 28,4 & 28,31 \\
18 & 28,4 & 28,31 \\
\hline
\end{tabular}

Tabel 3 Perbandingan geseran kimia senyawa hasil isolasi dengan artonin E standar ${ }^{[8]}$.

\begin{tabular}{|c|c|}
\hline 1H-NMR, $\delta(\mathrm{ppm})$ & 13C-NMR, $\delta(\mathrm{ppm})$ \\
\hline $6,15(\mathrm{H}-6)$ & $162,82(\mathrm{C}-7) ; 101,69(\mathrm{C}-8)$ \\
$6,59\left(\mathrm{H}-3^{\prime}\right)$ & $149,80\left(\mathrm{C}-2^{\prime}\right) ; 111,6\left(\mathrm{C}-1^{\prime}\right) ; 139,14\left(\mathrm{C}-5^{\prime}\right)$ \\
$6,87\left(\mathrm{H}-6^{\prime}\right)$ & $162,22(\mathrm{C}-2) ; 149,8\left(\mathrm{C}-2^{\prime}\right) ; 139,14\left(\mathrm{C}^{\prime}\right)$ \\
$3,14(\mathrm{H}-9)$ & $162,22(\mathrm{C}-2) ; 183,34(\mathrm{C}-4)$ \\
$6,62\left(\mathrm{H}^{\prime}-14\right)$ & $160,12(\mathrm{C}-8 \mathrm{a})$ \\
$5,65(\mathrm{H}-15)$ & $101,69(\mathrm{C}-8)$ \\
\hline
\end{tabular}

Tabel 4 Korelasi HMBC ${ }^{1} \mathrm{H}-\mathrm{NMR}$ dengan ${ }^{13} \mathrm{C}-\mathrm{NMR}$ senyawa hasil isolasi.

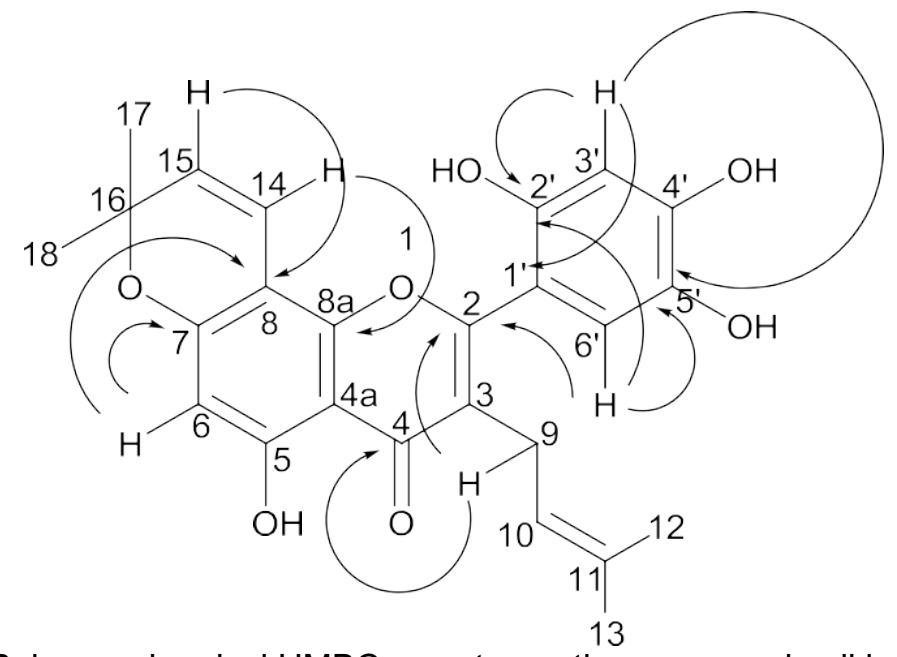

Gambar 7 Beberapa korelasi HMBC yang terpenting senyawa hasil isolasi (1). 


\section{Kesimpulan}

Berdasarkan penelitian yang telah dilakukan maka dapat disimpulkan sebagai berikut:

1. Senyawa flavonoid yang berhasil diisolasi dari kulit akar tumbuhan sukun (A. altilis) yaitu artonin $E$ berdasarkan hasil analisis spektroskopi ultraviolet-tampak (UV-Vis), inframerah (IR), dan resonansi magnetik inti (NMR).

2. Senyawa artonin $E$ yang berhasil diisolasi memiliki data fisik berupa kristal amorf berwarna kuning dengan titik leleh sebesar $247,5-249^{\circ} \mathrm{C}$.

\section{Penghargaan}

Ucapan terima kasih penulis sampaikan kepada Ibu Prof. Dr. Tati Suhartati, M.S. yang telah membantu dan membimbing penulis dalam menyelesaikan penelitian ini. Ucapan terima kasih penulis juga sampaikan keapada laboran kimia organik yang telah membantu penulis dalam menyiapkan peralatan yang dibutuhkan untuk menyelesaikan penelitian ini.

\section{Daftar Pustaka}

[1] T. Ersam, "Keunggulan Biodiversitas Hutan Tropika Indonesia dalam Merekayasa Model Molekul Alami", dipresentasikan pada Seminar Nasional VI, ITS, Surabaya, 2004.

[2] R. B. Herbert, Biosintesis Metabolit Sekunder. Alih Bahasa Bambang Srigandono, Semarang: IKIP Semarang Press, 1996, HIm 103-123.

[3] E. H. Hakim, E. L.Ghisalberti, S. A. Achmad, L. D. Juliawaty, L. Makmur, Y. M. Syah, N. Aimi, M. Kitajima, dan H. Takayama, "Prenylated Flavonoids and Related Compounds of The Indonesian Artocarpus (Moraceae)", J. Nat. Med, 60 (161-184), 2006.

[4] Z. Nurachman, Artoindinesianin Untuk Antitumor, Jakarta: PT Kompas Cyber Media, 2002.

[5] T. Ersam, "Senyawa Kimia Makromolekul Beberapa Tumbuhan Artocarpus Hutan Tropika Sumatera Barat" Tesis. Jurusan Kimia ITB, Bandung, 2001.

[6] B. Mursito, Ramuan Tradisional Untuk Penyakit Malaria, Jakarta: Penebar Swadaya, 2002.

[7] K. R. Markham, Cara Mengidentifikasi Flavonoid, Bandung: ITB, 1998, HIm 1-113.

[8] T. Suhartati, Yandri, and S. Hadi, "The Bioactivity Test of Artonin E from the Bark of Artocarpus rigida Blume" European Journal of Scientific Research, ISSN 1450-216X Vol. 23 No. 2 pp 330337, 2008.

[9] T. Suhartati, "Senyawa Fenol Beberapa Spesies Tumbuhan Jenis Cempedak Indonesia", Disertasi, Jurusan Kimia ITB, Bandung, 2001. 